\title{
Analisa Pendugaan Laju Erosi Dengan Menggunakan Model Agricultural Non Point Source Pollution (AGNPS) Di Sub Das Lesti Kabupaten Malang
}

\author{
Muhammad Fariz Kasyful Haq ${ }^{1 *}$, Moh. Sholichin ${ }^{1}$, Runi Asmaranto ${ }^{1}$ \\ ${ }^{1}$ Jurusan Teknik Pengairan, Fakultas Teknik, Universitas Brawijaya, \\ Jalan MT. Haryono No.167, Malang, 65145, INDONESIA \\ *Korespondensi Email: mfarizkh@gmail.com
}

Abstract: Changes in landuse and the topographic are undulating and hilly with a slope of $8-45 \%$, as well as the intensity of precipitation impacts on increased erosion rates in sub-watershed Lesti area. Continuous erosion of land causes shallows rivers in Sub-watershed Lesti. An analysis and mapping of the greater existential rates on erosion and sedimentation along with the erosion of subwatershed Lesti as well as land conservation efforts to reduce the effects of such erosion. Calculations using a model Agricultural Non-Point Source Pollution (AGNPS) obtained an average watershed erosion rate of 163,119 tons / ha / year. The results analysis of the danger erosion levels and area based on erosion danger index by hammer (1981) is obtained with a low level index $(<1) 13,770 \mathrm{~km}^{2}$, a moderate level (index 1-4) 13,521 km², a high level (index 4-10) $14,623 \mathrm{~km}^{2}$, and an exorbitant level (index >10) $16,342 \mathrm{~km}^{2}$. Based on sediment delivery ratio (SDR), results of sediment are 144,820.54 tons / year or 120,683.96 m3 / year. The conservation of land to reduce the rate of erosion are carried out in several ways, either by using vegetative and mechanical methods.

Keywords:, AGNPS, conservation of land, erosion, erosion hazard level, sediment

Abstrak: Perubahan tata guna lahan dan bentuk topografi yang berombakbergelombang dan berbukit bergunung dengan kemiringan lereng 8-45\%, serta besarnya intensitas curah hujan berdampak pada tingginya laju erosi di wilayah Sub DAS Lesti. Erosi lahan yang terus menerus terjadi menyebabkan pendangkalan pada sungai di Sub DAS Lesti. Oleh karena itu dilakukan analisa dan melakukan pemetaan tentang kondisi eksisting besarnya laju erosi dan sedimentasi beserta tingkat bahaya erosi pada Sub DAS Lesti dan juga upaya konservasi lahan guna untuk mengurangi dampak dari laju erosi tersebut. Perhitungan menggunakan model Agricultural Non-Point Source Pollution (AGNPS) diperoleh laju erosi ratarata DAS sebesar 163,119 ton/ha/tahun. Hasil analisis tingkat bahaya erosi berdasarkan Indeks Bahaya Erosi oleh Hammer (1981) diperoleh indeks dengan tingkat rendah (indeks $<1$ ) seluas $13,770 \mathrm{~km}^{2}$, tingkat sedang (indeks $1-4$ ) seluas $13,521 \mathrm{~km}^{2}$, dan tingkat sangat tinggi (indeks $>10$ ) seluas $14,623 \mathrm{~km}^{2}$, tingkat tinggi (indeks 4-10) seluas $16,342 \mathrm{~km}^{2}$. Berdasarkan hasil perhitungan sediment delivery ratio (SDR), didapatkan hasil perkiraan sedimen sebesar 144.820,54 ton/tahun atau $120.683,96 \mathrm{~m}^{3} /$ tahun. Upaya konservasi lahan guna untuk mengurangi besarnya

*Penulis korespendensi: mfarizkh@gmail.com 
laju erosi dilakukan dengan beberapa cara baik dengan menggunakan metode vegetatif maupun metode mekanik.

Kata Kunci: AGNPS, erosi, konservasi lahan, sedimen, tingkat bahaya erosi

\section{Pendahuluan}

Pengelolaan Daerah Aliran Sungai (DAS) merupakan suatu bentuk pengembangan dan pemanfaatan wilayah yang menempatkan DAS sebagai satu unit pengelolaan sumber daya alam (SDA) [1].

Sub DAS Lesti yang merupakan bagian dari DAS Brantas terletak pada Kabupaten Malang, dimana bagian hulu berada disebelah timur Kabupaten Malang yang memberikan kontribusi debit air sungai yang besar ke bagian hilir Kabupaten Malang, tepatnya di Bendungan Sengguruh dan Bendungan Sutami. Bendungan Sengguruh sebagai pembangkit listrik tenaga air (PLTA) mengalami penurunan produksivitas akibat penumpukan sampah dan sedimentasi. Hal ini disebabkan oleh penggunaan lahan yang tidak sesuai dengan kemampuan lahan dalam melindungi tanah dari erosi. Hal ini sangat berdampak pada pendangkalan sungai di wilayah Sub DAS Lesti.

Tujuan dari studi ini untuk mengetahui besarnya laju erosi di Sub DAS Lesti, mengetahui kondisi Tingkat Bahaya Erosi (TBE), dan konservasi lahan yang sesuai dengan kondisi Sub DAS Lesti dengan menggunakan model terdistribusi Agricultural non Point Source Pollution (AGNPS) serta program ArcgGIS.

\section{Bahan dan Metode}

\subsection{Lokasi Studi}

Studi ini dilakukan di wilayah Sub DAS Lesti dengan luas 58256 Ha. Secara administrasi, Lesti terdiri dari 12 wilayah kecamatan yang terdiri dari 89 desa.Secara geografis sungai Lesti yang berada pada titik koordinat $7^{\circ} 40^{\prime} 00^{\prime \prime}$ - $7^{\circ} 55^{\prime} 00^{\prime}$ ' Lintang Selatan dan $112^{\circ} 10^{\prime} 00^{\prime \prime}-112^{\circ} 25^{\prime} 00^{\prime \prime}$ Bujur Timur merupakan anak sungai dari Kali Brantas, yang bermata air dari lereng Gunung Semeru.

\subsection{Bahan}

Dalam studi ini diperlukan data sebagai penunjang dalam penyelesaian studi ini, datadata yang di butuhkan adalah sebagai berikut:

1. Data Stasiun Hujan pada Sub DAS Lesti

a. Data curah hujan tahun $2009-2018$

b. Koordinat stasiun hujan pada Sub DAS Lesti

2. Peta digital dalam format shapefile (.shp) maupun tiff-file (.tiff)
a. Peta Digital Elevation Model (DEM)
b. Peta administrasi pada Sub DAS Lesti
c. Peta Daerah Aliran Sungai (DAS) Lesti
d. Peta penggunaan lahan pada Sub DAS Lesti
e. Peta jenis tanah pada Sub DAS Lesti
f. Peta kemiringan lereng pada Sub DAS Lesti 
2.3. Metode

\subsubsection{Uji Konsistensi Data Curah Hujan}

Uji konsistensi data curah hujan menggunakan Metode Kurva Massa Ganda (Double Mass Curve) [2].

$$
\begin{array}{cc}
\operatorname{tg} \alpha=\frac{Y z}{X z} & \text { Pers. } 1 \\
\operatorname{tg} \alpha_{o}=\frac{Y_{O}}{X_{O}} & \text { Pers. } 2 \\
B C=\frac{\operatorname{tg} \alpha}{\operatorname{tg} \alpha_{o}} B C^{\prime} & \text { Pers. } 3
\end{array}
$$

dengan:

$\mathrm{BC}=$ data hujan yang diperbaiki $(\mathrm{mm})$

$\mathrm{BC}^{\prime}=$ data hujan hasil pengamatan $(\mathrm{mm})$

$\operatorname{Tg} \alpha \quad=$ Kemiringan sebelum ada perubahan

$\operatorname{Tg} \alpha_{\mathrm{o}}=$ kemiringan setelah ada perubahan

\subsubsection{Uji Stasioner}

Uji stasioner dilakukan dengan membagi data menjadi 2 kelompok. Deret data kemudian diuji kestabilan variannya menggunakan uji-F. Apabila hasil uji varian diterima, maka dilanjutkan dengan menguji kestabilan reratanya dengan uji-t [3].

1. Uji Kestabilan Varian (Uji-F)

$\mathrm{H}_{0}=$ rata-rata data stabil

$\mathrm{H}_{1}=$ rata-rata data stabil

$$
F=\frac{N_{1} S_{1}^{2}\left(N_{2}-1\right)}{N_{2} S_{2}^{2}\left(N_{1}-1\right)} \quad \text { Pers. } 4
$$

dengan:

$\mathrm{F} \quad=$ nilai hitung uji- $\mathrm{F}$

$\mathrm{N}_{1,2} \quad=$ jumlah data kelompok 1,2

$\mathrm{S}_{1,2} \quad=$ standar deviasi data kelompok 1,2

dengan derajat bebas $(\mathrm{df})$ :

$\begin{array}{ll}\text { df1 } & =\mathrm{N}_{1}-1 \\ \mathrm{df} 2 & =\mathrm{N}_{2}-1\end{array}$

Menentukan F kritis yang diperoleh dari tabel uji F dengan derajat kebebasan :

Df $\quad=\mathrm{N}_{1}+\mathrm{N}_{2}-2$

Pengambilan keputusan :

F hitung < $\mathrm{F}$ kritis maka $\mathrm{H}_{0}$ diterima

$\mathrm{F}$ hitung $>\mathrm{F}$ kritis maka $\mathrm{H}_{0}$ ditolak 
2. Uji Kestabilan Rata-Rata (Uji-T)

$\mathrm{H}_{0}=$ rata-rata data stabil

$\mathrm{H}_{1}=$ rata-rata data stabil

$$
\begin{array}{cc}
\sigma=\left(\frac{N_{1} S_{1}^{2}+N_{2} S_{2}^{2}}{N_{1}+N_{2}-2}\right)^{0,5} & \text { Pers. } 5 \\
t=\frac{\bar{X}_{1}-\bar{X}_{2}}{\sigma\left(\frac{1}{N_{1}}+\frac{1}{N_{2}}\right)^{0,5}} & \text { Pers. } 6
\end{array}
$$

dengan:

$\mathrm{T} \quad=$ nilai hitung uji-t

$\mathrm{N}_{1,2} \quad=$ jumlah data kelompok 1,2

$\mathrm{X}_{1,2} \quad=$ nilai rata-rata data kelompok 1,2

$\mathrm{S}_{1,2} \quad=$ standar deviasi data kelompok 1,2

Menenukan t kritis yang diperoleh dari tabel uji-t dengan derajat kebebasan:

$\mathrm{Df}=\mathrm{N}_{1}+\mathrm{N}_{2}-2$

Pengambilan keputusan:

t hitung $<\mathrm{t}$ kritis maka $\mathrm{H}_{0}$ diterima

$\mathrm{t}$ hitung $>\mathrm{t}$ kritis maka $\mathrm{H}_{0}$ ditolak

\subsubsection{Metode Poligon Thiessen}

Curah hujan rerata daerah dengan metode polygon thiessen dapat dihitung menggunakan persamaan sebagai berikut [4]:

$$
\bar{p}=\frac{A_{1} p_{1}+A_{2} p_{2}+A_{3} p_{3}+\cdots A_{n} p_{n}}{A_{1}+A_{2}+\cdots+A_{n}} \quad \text { Pers. } 7
$$

dengan:

$\bar{p} \quad=$ hujan rerata daerah

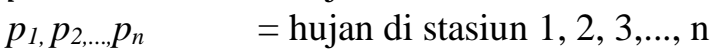

$\mathrm{A}_{1}, \mathrm{~A}_{2, \ldots}, \mathrm{A}_{\mathrm{n}} \quad=$ luas daerah yang mewakili stasiun $1,2,3, \ldots, \mathrm{n}$

\subsubsection{Pendugaan Laju Erosi Metode AGNPS}

Model AGNPS (Agricultural Non Point Source Pollution Model), dikembangkan oleh Robert A. Young (1987) di North Central Soil Conservation Research Laboratory, USDAAgricultural Research Service, Morris, Minnesota [5]. Model AGNPS merupakan gabungan antara model distribusi dan model sekuensial. Sebagai model distribusi, penyelesaian persamaan keseimbangan massa dilakukan serempak untuk semua sel. Sebagai model sekuensial, air dan cemaran sedimen dalam rangkaian aliran di permukaan lahan dan di saluran secara berurutan. Adapun persamaan yang digunakan pada model AGNPS adalah sebagai berikut [6]:

$$
E=E l_{30} . K \cdot L S . C \cdot P \cdot S S F \quad \text { Pers. } 8
$$

dengan:

$\mathrm{E}=$ erosi potensial (ton/acre) 


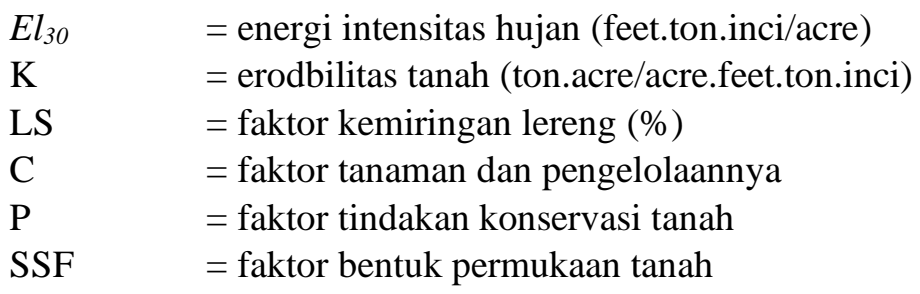

\subsubsection{Energi Intensitas Hujan $\left(\mathrm{EI}_{30}\right)$}

Energi intensitas hujan $\left(\mathrm{EI}_{30}\right)$ dapat dihitung dengan persamaan sebagai berikut [6]:

$$
E I_{30}=6,119(R A I N)^{1.21}(D A Y S)^{-047}(M A X P)^{0,53} \quad \text { Pers. } 9
$$

RAIN adalah curah hujan rata-rata bulanan dalam $\mathrm{cm}, D A Y S$ adalah jumlah hari hujan rata-rata perbulan, dan $M A X P$ adalah curah hujan harian maksimum bulanan dalam bulan yang bersangkutan dalam $\mathrm{cm}$. $\mathrm{El}_{30}$ adalah erosivitas hujan bulanan. $\mathrm{El}_{30}$ tahunan adalah jumlah $\mathrm{El}_{30}$ bulanan.

\subsubsection{Erodibilitas Tanah (K)}

Nilai erodibilitas tanah yang telah didapatkan pada Sub DAS Lesti berdasarkan jenis tanah kemudian di tentukan nilai erodibilitas tanah $(\mathrm{K})$ berdasarkan tabel nilai erodibilitas tanah [7].

Tabel 1. Nilai Erodibilitas Tanah (K) Berdasarkan Jenis Tanah [7]

\begin{tabular}{lll}
\hline No. & Jenis Tanah & Nilai K \\
\hline 1 & Kompleks mediteran coklat dan litosol & 0,47 \\
2 & Latosol & 0,31 \\
3 & Regosol & 0,12 \\
4 & Litosol & 0,29 \\
5 & Mediteran & 0,23 \\
\hline
\end{tabular}

\subsubsection{Kemiringan Lereng (LS)}

Faktor panjang dan kemiringan lereng adalah perbandingan antara besarnya erosi per indeks erosi dari suatu lahan dengan panjang dan kemiringan lahan tertentu terhadap besarnya erosi dari suatu lahan percobaan, tidak berdimensi [8].

Tabel 2. Nilai LS Berdasarkan Kemiringan Lereng [8]

\begin{tabular}{lll}
\hline No. & Kemiringan & LS \\
\hline 1 & $0-8 \%$ & 0,40 \\
2 & $8-15 \%$ & 1,40 \\
3 & $15-25 \%$ & 3,10 \\
4 & $25-40 \%$ & 6,8 \\
5 & $>40 \%$ & 9,5 \\
\hline
\end{tabular}

2.3.4.4. Faktor Pengelolaan Tanaman (C) dan Konservasi Tanah (P)

Vegetasi dan tindakan konservasi tanah juga mempengaruhi tingkat erosi yang terjadi. Areal yang tidak ditanami dan tidak ada tindakan konservasi nilai erosinya lebih besar dibanding areal yang kondisi vegetasinya baik dan dikonservasi. 


\subsubsection{Faktor SSF}

Faktor bentuk permukaan tanah merupakan salah satu dari masukan model AGNPS

Tabel 3. Nilai SSF [6]

\begin{tabular}{ll}
\hline Bentuk Permukaan Tanah & Nilai SSF \\
\hline Datar & 1 \\
Cekung & 2 \\
Cembung & 3 \\
\hline
\end{tabular}

\subsubsection{Pendugaan Tingkat Bahaya Erosi}

Tingkat bahaya erosi dinyatakan dalam indeks bahaya erosi dengan persamaan sebagai berikut [7]:

$$
\text { Indeks Bahaya Erosi }=\frac{\text { Erosi Potensial }(\text { ton } / \text { ha } / \text { th })}{T(\text { ton } / \text { ha } / \text { th })} \quad \text { Pers. } 10
$$

dengan:

$\mathrm{T}=$ Erosi yang di perbolehkan (ton/ha/th)

2.3.6. Erosi yang diperbolehkan (TSL)

Penetapan nilai Tolerable Soil Loss (TSL) berdasarkan konsep kedalamam ekuivalen dan umur guna tanah. Satuan erosi yang diperbolehkan sama dengan besar laju erosi yakni ton/ha/tahun. Nilai Tolerable Soil Loss (TSL) dapat dirumuskan sebagai berikut [6]:

$$
\mathrm{T}=\frac{\text { kedalam efektif } \mathrm{x} \text { faktor kedalaman tanah }}{\text { usia guna lahan }} \mathrm{x} \text { berat isi tanah } \quad \text { Pers. } 11
$$

Tabel 4. Klasifikasi Indeks Bahaya Erosi

\begin{tabular}{lc}
\hline Nilai IBE & Harkat \\
\hline$<1,0$ & Rendah \\
$1,0-4,0$ & Sedang \\
$4,01-10,0$ & Tinggi \\
$>10,01$ & Sangat Tinggi \\
\hline
\end{tabular}

\subsubsection{Sedimentasi}

Sedimen Delivery Ratio (SDR) didapat dengan persamaan Boyce [9]:

$$
\operatorname{SDR}=0,41 \cdot \mathrm{A}^{-0,3} \quad \text { Pers. } 12
$$

dengan:

$$
\begin{array}{ll}
\mathrm{SDR} & =\text { sediment delivery ratio } \\
\mathrm{A} & =\text { luas DAS (ha) }
\end{array}
$$

Dalam perkiraan besarnya sedimen dapat dihitung dengan rumus berikut [10]:

$$
\mathrm{Y}=\mathrm{E} \times \mathrm{SDR} \times \mathrm{A} \quad \text { Pers. } 13
$$

dengan:

$\mathrm{Y} \quad=$ hasil sedimen (ton/tahun) 


$$
\begin{array}{ll}
\mathrm{E} & =\text { erosi lahan (ton } / \mathrm{ha} / \mathrm{th}) \\
\mathrm{SDR} & =\text { sediment delivery ratio } \\
\mathrm{A} & =\text { luas DAS (ha) }
\end{array}
$$

\section{Hasil dan Pembahasan}

\subsection{Uji Kurva Massa Ganda}

Uji konsistensi dengan kurva massa ganda. Terdapat 5 stasiun hujan yang akan diuji datanya yaitu stasiun Dampit, stasiun Pagak, stasiun Poncokusumo, Stasiun Tumpak Renteng, stasiun Turen. Dari hasil uji tersebut didapat curah hujan terkoreksi yang tersaji pada Tabel 5.

Tabel 5. Curah Hujan Terkoreksi

\begin{tabular}{cccccc}
\hline \multirow{2}{*}{ Tahun } & \multicolumn{5}{c}{ Data Curah Hujan } \\
\cline { 2 - 6 } & $\begin{array}{c}\text { Stasiun } \\
\text { Dampit }\end{array}$ & $\begin{array}{c}\text { Stasiun } \\
\text { pagak }\end{array}$ & $\begin{array}{c}\text { Stasiun } \\
\text { Poncokusumo }\end{array}$ & $\begin{array}{c}\text { Stasiun Tumpak } \\
\text { Renteng }\end{array}$ & $\begin{array}{c}\text { Stasiun } \\
\text { Turen }\end{array}$ \\
\hline 2009 & 1888 & 933 & 2183 & 1701 & 1576 \\
2010 & 3377 & 2087 & 3367 & 4339 & 3721 \\
2011 & 1576 & 1576 & 1739 & 1922 & 1590 \\
2012 & 1631 & 1878 & 1864 & 1634 & 1826 \\
2013 & 1760 & 1953 & 2508 & 2107 & 2497 \\
2014 & 1548 & 1260 & 1656 & 1780 & 1441 \\
2015 & 1724 & 1587 & 1591 & 1514 & 2098 \\
2016 & 3292 & 3330 & 2657 & 2775 & 3024 \\
2017 & 1626 & 1560 & 2386 & 2075 & 1971 \\
2018 & 2352 & 1169 & 1434 & 1325 & 1594 \\
\hline
\end{tabular}

\subsection{Uji Stasioner}

Uji Stasioner dilakukan dengan menggunakan Uji-F dan Uji-T pada 5 stasiun hujan yang akan diuji yaitu staisun Dampit, stasiun Pagak, stasiun Poncokusumo, Stasiun Tumpak Renteng, stasiun Turen.

Tabel 6. Rekapitulasi Uji Stasioner

\begin{tabular}{cccccc}
\hline \multirow{2}{*}{ Rekapitulasi } & \multicolumn{5}{c}{ Stasiun } \\
\cline { 2 - 6 } & Dampit & Pagak & Poncokusumo & Tumpak Renteng & Turen \\
\hline Uji-F & Stabil & Stabil & Stabil & Stabil & Stabil \\
Uji-T & Stabil & Stabil & Stabil & Stabil & Stabil \\
\hline
\end{tabular}

Hasil dari uji $\mathrm{F}$ dengan pengujian dua sisi didapat Fhitung $<$ Ftabel $=6,390$ artinya data menunjukkan stabil, sedangkan pada uji T dengan pengujian satu sisi Thitung < Ttabel $=2,064$ artinya data menunjukkan stabil.

\subsection{Pembangkitan Data Model AGNPS}

\subsubsection{Pembuatan Peta DAS dan Sel Model AGNPS}

Pembuatan peta DAS dalam studi ini menggunakan software ArcGIS 10.3 dengan menggunakan data DEM. Setelah melakukan pembuatan peta DAS, kemudian dilanjutkan dengan menggambarkan areal DAS ke dalam tingkatan sel berbentuk persegi dengan prosses gridding dan diberi penomoran pada tiap sel. 


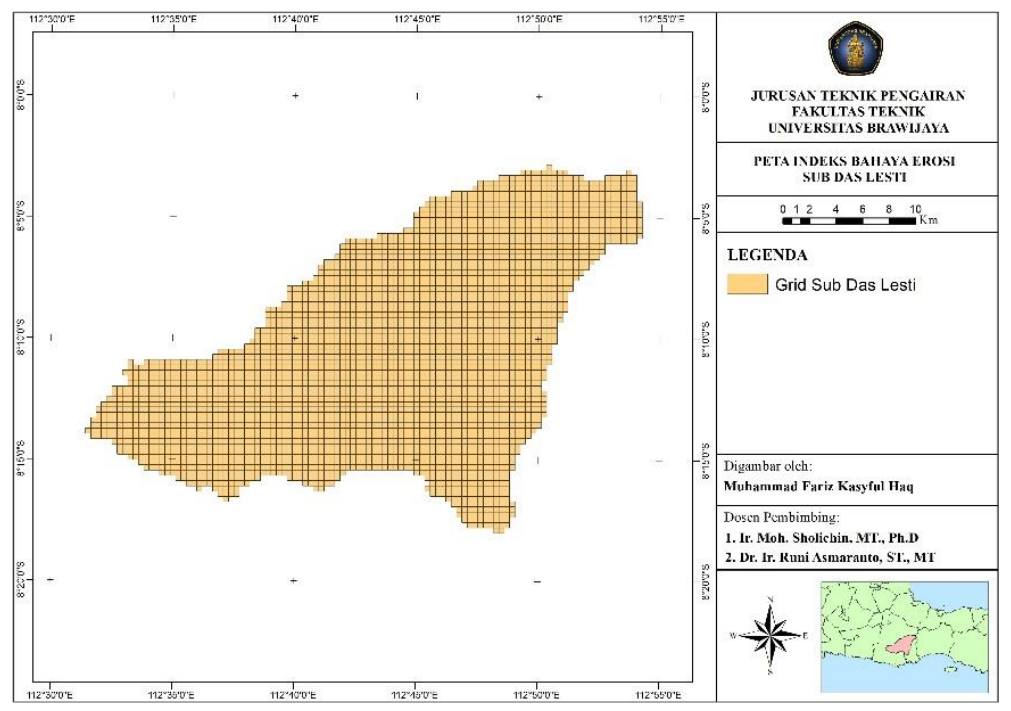

Gambar 1 : Peta Grid Sub DAS Lesti

Pada luas Sub DAS Lesti mengalami penyusutan sesuai jumlah sel yang didapatkan setelah proses gridding. Luas Sub DAS Lesti mengalami penyusutan $59,196 \mathrm{~km}^{2}$, diperoleh sel sebanyak 3641 atau seluas $58,256 \mathrm{~km}^{2}$ atau berkurang sebesar $(0,016 \%)$.

\subsubsection{Perhitungan Erosivitas Hujan}

Dari analisa hidrologi, maka didapat nilai erosivitas hujan tahunan $\left(\mathrm{EI}_{30}\right)$ pada masingmasing stasiun yang kemudian dilakukan pembobotan luas pengaruh stasiun dengan poligon thiessen menggunakan ArcGIS. Berikut nilai erosivitas hujan tahunan dapat dilihat pada Tabel 4.

Tabel 7. Erosivitas Hujan Tahunan pada Stasiun Hujan

\begin{tabular}{cccccc}
\hline No & Stasiun & $\mathrm{EI}_{30}$ & Jumlah Sel & Luas $\left(\mathrm{km}^{2}\right)$ & Presentase(\%) \\
\hline 1 & Dampit & 2176,57 & 1215 & 194,32 & 33,34 \\
2 & Pagak & 1555,39 & 457 & 73,13 & 12,56 \\
3 & Poncokusumo & 1681,12 & 792 & 126,70 & 21,75 \\
4 & Tumpak Renteng & 2027,66 & 391 & 62,51 & 10,73 \\
5 & Turen & 1757,3 & 787 & 125,90 & 21,61 \\
\hline & Total & & 3641 & 58,256 & 100 \\
\hline
\end{tabular}

\subsubsection{Penentuan Nilai LS}

Dalam penentuan nilai LS berdasarkan kemiringan lereng yang kemudian diinput kedalam peta kemiringan lereng. Maka diperoleh hasil sebagai berikut:

Tabel 8. Sebaran Nilai LS

\begin{tabular}{ccccc}
\hline No & Kemiringan & LS & Jumlah Sel & Luas $\left(\mathrm{km}^{2}\right)$ \\
\hline 1 & $0-8$ & 0,4 & 2026 & 324,22 \\
2 & $08-15$ & 1,4 & 739 & 118,21 \\
3 & $15-25$ & 3,1 & 444 & 71,01 \\
4 & $25-40$ & 6,8 & 219 & 35,09 \\
5 & $>40 \quad$ & 9,5 & 213 & 34,04 \\
\hline \multicolumn{2}{r}{ Total } & & 3641 & 582,56 \\
\hline
\end{tabular}




\subsubsection{Penentuan Nilai Erodibilitas Tanah (K)}

Nilai Erodibilitas tanah (K) ditentukan dari tabel indeks erodibilitas tanah berdasarkan pengolahan peta jenis tanah di Sub DAS Lesti. Maka diperoleh nilai faktor K sebagai berikut:

Tabel 9. Sebaran Nilai Erodibilitas Tanah (K)

\begin{tabular}{cccccc}
\hline No & Stasiun & $\mathrm{EI}_{30}$ & Jumlah Sel & Luas $\left(\mathrm{km}^{2}\right)$ & Presentase $(\%)$ \\
\hline 1 & Dampit & 2176,57 & 1215 & 194,32 & 33,34 \\
2 & Pagak & 1555,39 & 457 & 73,13 & 12,56 \\
3 & Poncokusumo & 1681,12 & 792 & 126,70 & 21,75 \\
4 & Tumpak Renteng & 2027,66 & 391 & 62,51 & 10,73 \\
5 & Turen & 1757,3 & 787 & 125,90 & 21,61 \\
\hline & Total & & 3641 & 582,56 & 100 \\
\hline
\end{tabular}

\subsubsection{Penentuan Faktor $\mathrm{C}$ dan $\mathrm{P}$}

Faktor pengelolaan tanaman (C) dan faktor tindakan konservasi tanah (P) yang didapatkan berdasarkan pengolahan peta tata guna lahan pada Sub DAS Lesti. Maka diperoleh niali faktor $\mathrm{C}$ dan $\mathrm{P}$ sebagai berikut:

Tabel 10. Sebaran Nilai Faktor $C$ dan $P$

\begin{tabular}{clllcc}
\hline No & Jenis Tutupan Lahan & $\mathrm{C}$ & $\mathrm{P}$ & Jumlah Sel & Luas $\left(\mathrm{km}^{2}\right)$ \\
\hline 1 & Permukiman & 0,01 & 1 & 482 & 77,16 \\
2 & Semak belukar & 0,3 & 0,021 & 100 & 15,92 \\
4 & Hutan & 0,2 & 0,4 & 279 & 44,93 \\
5 & Rumput & 0,02 & 0,04 & 3 & 0,58 \\
6 & Sawah tadah hujan & 0,1 & 0,013 & 34 & 5,47 \\
7 & Sawah Irigasi & 0,5 & 0,013 & 391 & 62,56 \\
8 & Ladang & 0,7 & 0,209 & 1373 & 219,44 \\
9 & Perkebunan & 0,2 & 0,5 & 964 & 154,06 \\
10 & Air Tawar & 0 & 0 & 15 & 2,45 \\
\hline & Total & & & 3641 & 582,56 \\
\hline
\end{tabular}

\subsubsection{Penentuan Nilai SSF}

Nilai SSF merupakan salah satu masukan pada model AGNPS untuk menunjukkan bentuk permukaan tanah. Nilai SSF didapatkan dengan melakukan pengolahan data DEM dengan tool curvature pada ArcGIS. Berikut nilai faktor SSF pada model AGNPS.

Tabel 11. Sebaran Nilai SSF

\begin{tabular}{|c|c|c|c|}
\hline Bentuk Permukaan Tanah & SSF & Jumlah Sel & Luas $\left(\mathrm{km}^{2}\right)$ \\
\hline Datar & 1 & 1527 & 244,36 \\
\hline Cekung & 2 & 341 & 54,46 \\
\hline Cembung & 3 & 1773 & 283,74 \\
\hline Total & & 3639 & 582,56 \\
\hline
\end{tabular}

Dari hasil pemetaan diperoleh sebaran nilai SSF pada setiap bentuk permukaan tanah datar sebesar $42 \%$, cekung sebesar $9 \%$ dan cembung sebesar $49 \%$ 


\subsection{Pemetaan Laju Erosi}

Perhitungan pendugaan laju erosi lahan eksisting dihitung untuk tiap sel dengan total 3641 sel yang mewakili 16 ha lahan pada Sub DAS Lesti.

Tabel 12. Sebaran Laju Erosi Sub DAS Lesti

\begin{tabular}{clllll}
\hline No. & Kelas & Laju Erosi (ton/ha/th) & Keterangan & Jumlah Sel & Luas $\left(\mathrm{km}^{2}\right)$ \\
\hline 1 & I & $<15$ & Sangat ringan & 981 & 156,89 \\
2 & II & $15-60$ & Ringan & 733 & 117,32 \\
3 & III & $60-180$ & Sedang & 802 & 128,34 \\
4 & IV & $180-480$ & Berat & 703 & 112,48 \\
5 & V & $>480$ & Sangat Berat & 422 & 67,54 \\
\hline \multicolumn{2}{c}{ Total } & & 3641 & 582,56 \\
\hline
\end{tabular}

Dari sebaran laju erosi di Sub DAS Lesti didapat reratanya sebesar 163,119 ton/ha/tahun atau setara dengan 13,593 mm/tahun. Laju erosi yang diperoleh melebihi batas maksimum laju erosi yang diperbolehkan (T) di Indonesia yaitu 2,55 mm/tahun.

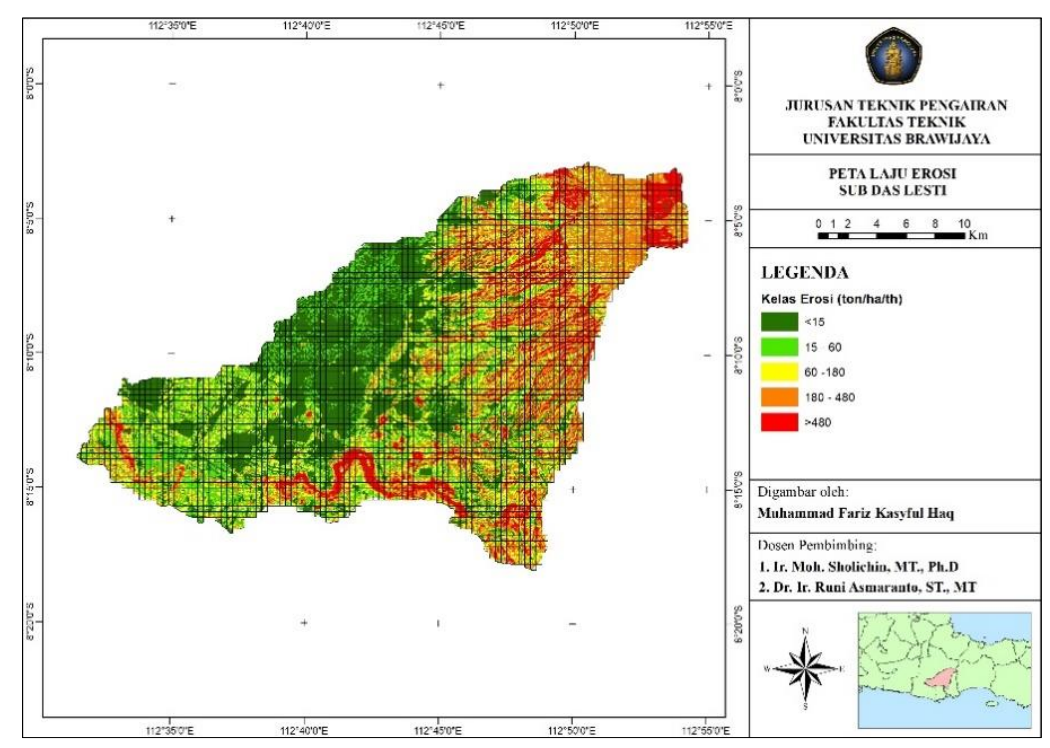

Gambar 2 : Peta Laju Erosi Sub DAS Lesti

\subsection{Laju Erosi yang Diperbolehkan}

Dengan pengolahan data erosi yang diperbolehkan pada peta grid Sub DAS Lesti, maka di peroleh hasil sebagai berikut:

Tabel 13. Rekapitulasi Nilai T Sub DAS Lesti

\begin{tabular}{lllllll}
\hline No & Jenis Tanah & $\begin{array}{l}\text { Bobot Isi Tanah } \\
(\mathrm{gr} / \mathrm{cm})\end{array}$ & $\begin{array}{l}\text { Faktor } \\
\text { Kedalaman }\end{array}$ & Solum Tanah & $\begin{array}{c}\mathrm{T} \\
\text { (ton/ha/th) }\end{array}$ \\
\hline 1 & Alluvial & 1,02 & 0,95 & 900 & 21,8025 \\
2 & Latosol & 0,93 & 1,00 & 900 & 20,925 \\
3 & Litosol & 0,97 & 0,90 & 600 & 13,095 \\
4 & Mediterian & 0,97 & 0,90 & 600 & 13,095 \\
5 & Regosol & 1,07 & 1,00 & 900 & 24,08 \\
\hline
\end{tabular}


Tabel 14. Sebaran Nilai T Sub DAS Lesti

\begin{tabular}{llll}
\hline No & TSL & Jumlah Sel & Luas $\left(\mathrm{km}^{2}\right)$ \\
\hline 1 & 13,095 & 758 & 12132 \\
2 & 20,925 & 1482 & 23713 \\
3 & 21,8025 & 443 & 7089 \\
4 & 24,075 & 958 & 15322 \\
\hline & Total & 3641 & 58256 \\
\hline
\end{tabular}

\subsection{Analisa Tingkat Bahaya Erosi}

Analisa ini untuk mengetahui kondisi suatu lahan dengan melihat tingkat erosi yang terjadi dan dibandingkan dengan laju erosi yang diijinkan menurut Hammer (1982).

Tabel 15. Indeks Bahaya Erosi Sub DAS Lesti

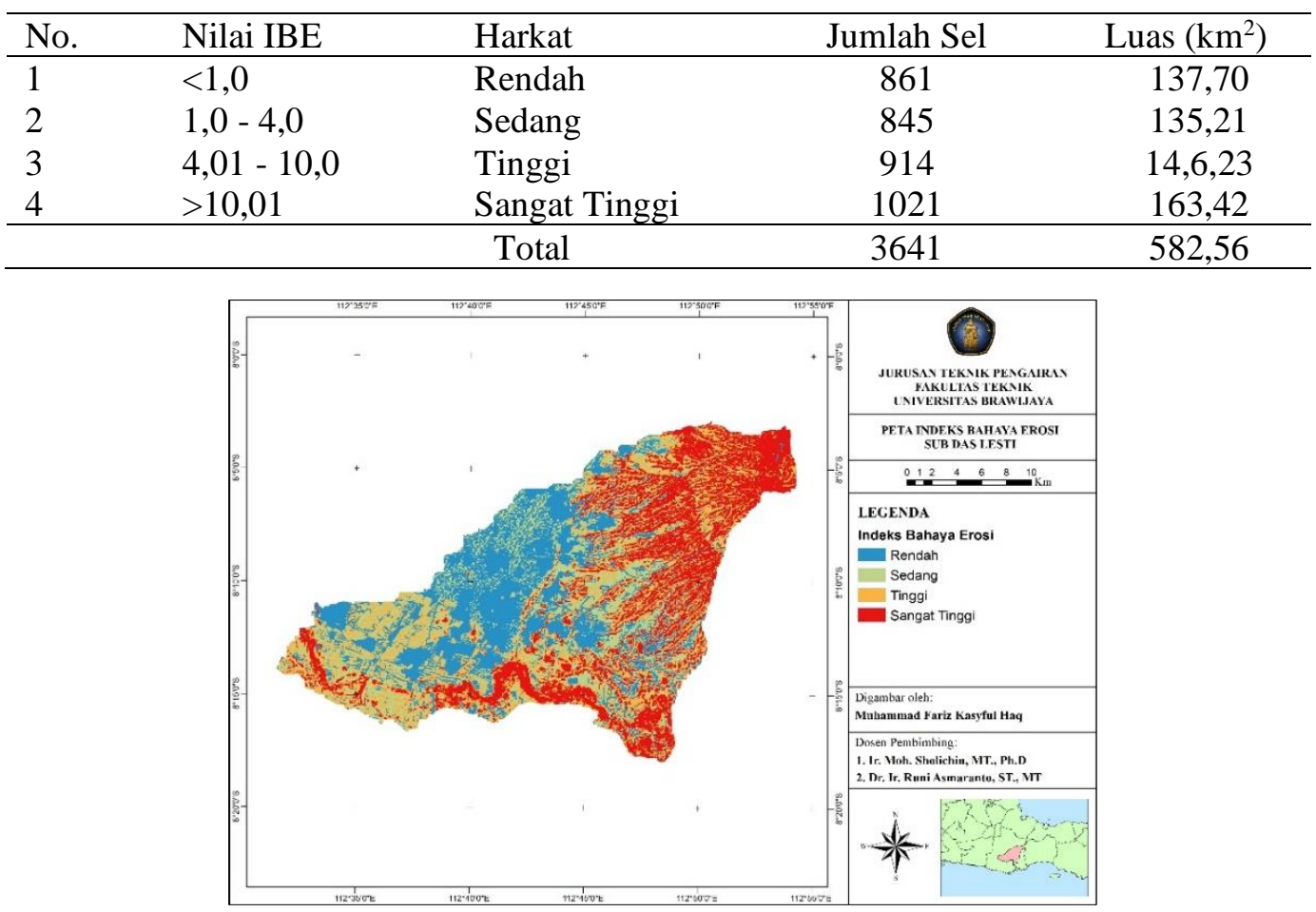

Gambar 3 : Peta Indeks Bahaya Erosi Sub DAS Lesti

\subsection{Sedimentasi}

Perhitungan besarnya sedimentasi dapat di hitung berdasarkan hasil erosi yang terjadi pada lahan. Perkiraan besarnya sedimen dihitung menggunakan rumus SCS-Nastional Engineering Handbook berdasarkan sediment delivery ratio (SDR) pada DAS.

Dengan nilai rata- rata laju erosi pada Sub DAS Lesti yang sudah didapat yakni 163,119 ton/ha/th, maka perkiraan hasil sedimen pada Sub DAS Lesti sebesar sebesar $144.820,54$ ton/th atau $120.683,96 \mathrm{~m}^{3} /$ th tanah yang tersedimentasi pada sungai.

\subsection{Konservasi Lahan}

Dilihat dari hasil analisa laju erosi di atas, di lakukan upaya konservasi lahan untuk mengurangi atau menekan angka laju erosi di Sub DAS Lesti. Upaya konservasi lahan 
dilakukan pada areal yang memiliki kerawanan erosi berdasarkan hasil analisa dengan cara metode vegetatif dan metode mekanik.

\section{Kesimpulan}

Dari hasil analisa yang telah dilakukan diperoleh hasil antara lain:

1. Dengan menggunakan model Agricultural Non-Point Source Pollution (AGNPS) didapat hasil rerata laju erosi eksisting pada Sub DAS Lesti sebesar 163,119 ton/ha/th.

2. Berdasarkan hasil laju erosi eksisting maka didapatkan tingkat bahaya erosi dengan sebaran indeks bahaya erosi kelas tingkat rendah (indeks < 1) seluas $137,70 \mathrm{~km}^{2}$, tingkat sedang (indeks 1-4) seluas $135,21 \mathrm{~km}^{2}$, tingkat tinggi (indeks 4-10) seluas $146,23 \mathrm{~km}^{2}$, sedangkan untuk sebaran indeks bahaya erosi dengan tingkat sangat tinggi (indeks $>10$ ) seluas $163,42 \mathrm{~km}^{2}$.

3. Besarnya perkiraan sedimen pada Sub DAS Lesti dengan menggunakan sedimen delivery ratio (SDR) diperoleh nilai sebesar 144.820,54 ton/th atau 120.683,96 $\mathrm{m}^{3} / \mathrm{th}$.

4. Upaya konservasi lahan untukmengurangi laju erosi dapat dilakukan dengan cara metode vegetatif dan metode mekanik.

\section{Daftar Pustaka}

[1] Bisri, M. Pengelolaan Daerah Aliran Sungai. Malang : CV Asrori, 2009

[2] Limantara , L. M. Analisa Hidrologi. Jakarta: PT. Gramedia Pustaka Utama, 1993

[3] Soewarno. Aplikasi Metode Statistik untuk Analisa Data (Vol. 1). Bandung: Nova, 1995

[4] Triatmodjo, B. Hidrologi Terapan. Yogyakarta: Beta Offset. 2016.Arsyad, S. Konservasi Tanah dan Air. Bogor: Institut Pertanian Bogor Press, 2012

[5] Young R. A., Charles A. O., Bosch D.D., Wyne P. A. AGNPS User's Guide Version 3.51. Minnesota: Agricultural Research Service, U.S Department of Agriculture, 1990

[6] Arsyad, S. Konservasi Tanah dan Air. Bogor: Institut Pertanian Bogor Press, 2012

[7] Soepardi, G. Sifat dan Ciri Tanah. Bogor: Institut Pertanian Bogor Press, 1983

[8] Menteri Kehutanan. Peraturan Menteri Kehutanan Republik Indonesia No: P.32/MENHUT-11/2009 tentang Tata Cara Penyusunan Rencana Teknik Rehabilitasi Hutan dan Lahan Daerah Aliran Sungai (RTRHLDAS). Jakarta: Kementerian Kehutanan, 2009

[9] Boyce. Sediment Routing and Sediment Delivery Ratios. Washington D.C: U.S Department of Agriculture, 1975

[10] Asdak, C. Hidrologi dan Pengelolaan Daerah Aliran Sungai. Yogyakarta: Gadjah Mada University Press, 2004 